\title{
Spirulina as a functional ingredient in broiler chicken diets
}

\author{
E. Bonos ${ }^{1}$, E. Kasapidou ${ }^{1}$, A. Kargopoulos ${ }^{1}$, A. Karampampas ${ }^{1}$, E. Christaki ${ }^{2 \#,}$ \\ P. Florou-Paneri' ${ }^{2}$ \& I. Nikolakakis ${ }^{1}$ \\ ${ }^{1}$ School of Agriculture Technology, Food Technology and Nutrition, Department of Agricultural Technology, \\ Technological Education Institute of Western Macedonia, Florina, Greece \\ ${ }^{2}$ School of Veterinary Medicine, Faculty of Health Sciences, Aristotle University of Thessaloniki, Thessaloniki, Greece
}

(Received 19 February 2015; Accepted 15 January 2016; First published online 23 March 2016)

Copyright resides with the authors in terms of the Creative Commons Attribution 2.5 South African Licence.

See: http://creativecommons.org/licenses/by/2.5/za

Condition of use: The user may copy, distribute, transmit and adapt the work, but must recognise the authors and the South African Journal of Animal Science.

\begin{abstract}
In recent years there has been increased interest in the production of novel functional foods by utilizing eco-friendly materials and methods. Therefore, the present study was undertaken to determine the effects of dietary spirulina (Spirulina platensis), a blue-green microalga, on growth performance, meat oxidative stability and fatty acid profile of broiler chickens. One hundred and twenty one-day-old broiler chickens of mixed sex were weighed individually and assigned randomly to three treatment groups with four replications of 10 birds. All birds were housed in floor cages with litter, and conventional breeding and management procedures were applied throughout the 42-day trial period. The treatment groups were as follows: control: $0 \mathrm{~g}$ spirulina/kg feed; S05: $5 \mathrm{~g}$ spirulina/kg feed; S10: $10 \mathrm{~g}$ spirulina/kg feed. The birds were fed with maize and soybean meal-based commercial diets for the starter (1 to 14 days), grower (15 to 28 days) and finisher (29 to 42 days) periods. Feed and drinking water were offered to all birds ad libitum. The results of the experiment showed that bodyweight gain (at $21 \mathrm{~d}$ and $42 \mathrm{~d}$ ), feed conversion ratio and mortality did not differ among the groups, nor did breast and thigh meat lipid oxidation differ among the groups. The fatty acid profile of the thigh meat was enriched in polyunsaturated fatty acids, especially eicosapentaenoic acid and docosahexaenoic acid after spirulina supplementation. Therefore, spirulina could be a promising functional ingredient in broiler chicken nutrition.
\end{abstract}

Keywords: Poultry, microalgae, performance, meat oxidative stability, fatty acid profile

\#Corresponding author: efchris@vet.auth.gr

\section{Introduction}

Nowadays consumers demand natural, safe and eco-friendly products that can promote health benefits beyond their nutritional value, improve well-being and limit the risk of some chronic diseases. Such foods are named functional foods or nutraceuticals, a concept that was born in Japan early in 1980 (Plaza et al., 2009; Christaki et al., 2011; Borowitzka, 2013).

Natural environments could be a crucial biological source of functional ingredients, for example algae, which constitutes a promising approach to developing novel foods (Lordan et al., 2011; Draaisma et al., 2013). Among edible algae, spirulina or arthrospira - a blue green microalga - has served recently as an important source of valuable bioactive compounds. Dried spirulina is a good nutritional source with a high protein content $(260-770 \mathrm{~g} / \mathrm{kg}$ ) and a significant lipid content (10 - $140 \mathrm{~g} / \mathrm{kg})$ (Ciferri, 1983; Ross \& Dominy, 1990; Spolaore et al., 2006; Becker, 2007; Habib et al., 2008; Alvarenga et al., 2011; Zahroojian et al., 2013). Spirulina is high in unsaturated and polyunsaturated fatty acids in particular $(25 \%-60 \%$ of the total fatty acids), such as oleic acid, linoleic acid, gamma-linolenic acid and docosahexaenoic (DHA) (Hue et al., 2002; Yukino et al., 2005; Habib et al., 2008). It has also been reported that the amino acid pattern of these microalgae could be comparable with or superior to that of other vegetable foods and feeds, and that they have a high nutrient digestibility (Spolaore et al., 2006; Plaza et al., 2009; Alvarenga et al., 2011). In addition, spirulina contains substances such as pigments (for example carotenoids such as $\beta$-carotene and zeaxanthin) (Maoka, 2011), phycobiliproteins (for example phycocyanin, which is unique in the cyanobacteria (Eriksen, 2008), vitamins (Becker, 1994), macro and micro mineral elements (Becker, 1994; Spolaore et al., 2006) and antioxidants (Christaki et al., 2013). These compounds reveal potential biological properties such as antimicrobial, antioxidant, anti-cancer and anti-inflammatory or act as immune enhancers and colorants (Freitas et al., 2012; Batista et al., 2013; Christaki et al., 2013). However, the total amount of 
nutrients in spirulina could be greatly affected by available nutrients and environmental conditions during growth (Ciferri, 1983; Tonon et al., 2002; Tzovenis et al., 2003; Spolaore et al., 2006; Habib et al., 2008), by harvesting and drying techniques (Borowitzka, 1988; Spolaore et al., 2006; Alvarenga et al., 2011) and by methods of nutrient determination (Ciferri, 1983).

Recently, the effects of spirulina supplementation on animal performance and quality of animal products have been examined in the diets of dairy cows (Simkus et al., 2007; Christaki et al., 2012), fattening lambs (EL-Sabagh et al., 2014), rabbits (Colla et al., 2008; Peiretti \& Meineri, 2008; Gerencser et al., 2014), common carp (Abdulrahman \& Hamad Ameed, 2014), pigs (Grinsteal et al., 2000), laying hens (Carrillo et al., 2008; Maries et al., 2012; Zahroojian et al., 2013) and broilers (Ross \& Dominy, 1990; Toyomizu et al., 2001; Alvarenga et al., 2011; Bellof \& Alarcon, 2013). Nevertheless, published data could not be found on the effects of dietary spirulina on chicken meat oxidative stability and fatty acid profile.

The rapid increase of poultry meat consumption in the last few decades is related to consumer beliefs that poultry meat is 'healthy' and costs less than red meat. The absence of cultural and religious restraints to poultry meat consumption is also important (Cavani et al., 2010; Petracci et al., 2013). The inclusion of spirulina in broiler nutrition, besides having possible favourable effects on health and performance (Ravi et al., 2010; Kharde et al., 2012; Holman \& Malau-Aduli, 2013; Shanmugapriya \& Saravana Babu, 2014), might be a simple and convenient strategy to introduce its bioactive compounds into the meat and produce functional products according to consumer demand for healthy natural foodstuffs (Jimenez-Colmenero et al., 2001).

Therefore, the present study was undertaken to determine the effects of dietary spirulina, as a natural functional ingredient, on the growth performance of broiler chickens, and the oxidative stability and fatty acid profile of their meat.

\section{Material and Methods}

The experiment was conducted at the School of Agriculture Technology, Food Technology and Nutrition, Department of Agricultural Technology, Technological Educational Institution of Western Macedonia, Florina, Greece, according to the ethical guidelines of the Regional Directorate of Agriculture and Veterinary Medicine of Greece.

One hundred and twenty one-day-old broiler chickens of mixed sex (as hatched) were assigned randomly to three treatment groups, with four replications of 10 birds per group. Initial bodyweight did not differ between the groups (average $49 \pm 0.7 \mathrm{~g}$ per chick). Each replication was housed for 42 days in floor cages with litter. Conventional breeding and management procedures were applied throughout the trial, according to the principles of the Greek Directorate General of Veterinary Services for the care of animals in experimentation.

The birds of the control group were fed with maize and soybean meal commercial diets: starter (1 - 14 days), grower (15 - 28 days) and finisher (29 - 42 days), based on the guidelines of NRC (1994). The birds of S05 were offered the same feeds with the addition of $5 \mathrm{~g}$ spirulina powder $/ \mathrm{kg}$, whereas S10 were offered these feeds with the addition of $10 \mathrm{~g}$ spirulina powder $/ \mathrm{kg}$. The dried spirulina in this trial was produced in the area of Serres, Greece. Feed and drinking water were offered to all birds ad libitum.

Table 1 presents the ingredients and the proximate chemical analysis, namely dry matter, crude protein, crude fat, crude fibre and ash (AOAC, 2005), of the three diets. Moreover, the calcium, total phosphorus, lysine, methionine plus cystine and metabolizable energy content were calculated from the composition of the feed ingredients, based on Novus (1992) and NRC (1994).

Throughout the trial, feed consumption and mortality were recorded daily. All birds were individually weighed weekly. At the end of the experiment, bodyweight gain and feed conversion ratio were calculated.

At day 42, two birds from each replication (1 male, 1 female) were randomly selected, and were slaughtered under commercial conditions. Skinless breast ( $m$. pectoralis superficialis) and thigh ( $m$. biceps femoris) samples were prepared to determine lipid oxidation and fatty acid composition. Skinless samples were used as they are more homogenous than muscles with their skin on and represent the type of poultry meat that is preferentially consumed in Europe (Rymer \& Givens, 2006). Samples were vacuum-packaged and placed at $-45^{\circ} \mathrm{C}$ for further analysis. Prior to analyses, the samples were thawed at $4{ }^{\circ} \mathrm{C}$ overnight.

Determination of the lipid oxidation of the samples was performed using a modified version of the method of Vyncke (1975), as described by Kasapidou et al. (2014). The previously frozen samples were placed in refrigeration $\left(4^{\circ} \mathrm{C}\right)$ for five days. On the second and the fifth day of refrigerated storage, each sample of breast muscles ( $m$. pectoralis superficialis) and thigh muscles ( $m$. biceps femoris) was separated from the bones and skin, and was trimmed of external/adjacent fat and connective tissue, and blended in a

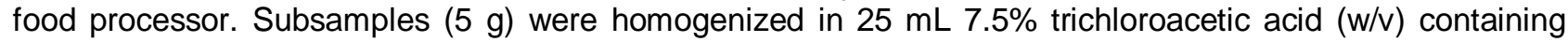
$0.1 \%(w / v)$ of both n-propyl gallate and ethylenediaminetetraacetic acid disodium salt, using a Polytron (Kinematica AG, Littau, Switzerland model PT-MR 3000). Samples were left for approximately 15 to 20 min 
to allow extraction of the thiobarbituric acid reacting substances (TBARS). The resulting residue was filtered, and $5 \mathrm{~mL}$ of the filtrate was mixed with $5 \mathrm{~mL} 0.02 \mathrm{M}$ thiobarbituric acid. A blank sample containing $5 \mathrm{~mL}$ of the trichloroacetic acid solution and $5 \mathrm{~mL}$ of the thiobarbituric acid solution was prepared. All samples were left in the dark overnight and on the following day absorbance was read at $532 \mathrm{~nm}$ against the blank sample, using an UV-VIS spectrophotometer (U-2800 Double Beam Spectrophotometer, Hitachi, Tokyo, Japan). TBARS were calculated using 1,1,3,3 tetraethoxypropane (5-20 nM) as standard and expressed as mg of malondialdehyde (MDA) per kg muscle. Each sample was analysed twice and the average value was used.

Table 1 Ingredients and chemical analysis of the experimental diets (as-fed basis)

\begin{tabular}{|c|c|c|c|}
\hline \multirow{2}{*}{ Ingredients (g/kg) } & \multicolumn{3}{|c|}{ Diets } \\
\hline & $\begin{array}{c}\text { Starter } \\
\mathbf{1} \mathrm{d}-\mathbf{1 4} \mathrm{d}\end{array}$ & $\begin{array}{c}\text { Grower } \\
15 d-28 d\end{array}$ & $\begin{array}{c}\text { Finisher } \\
29 \mathrm{~d}-42 \mathrm{~d}\end{array}$ \\
\hline Maize & 509.1 & 560.0 & 637.3 \\
\hline Soybean meal & 339.0 & 342.0 & 283.0 \\
\hline Herring meal & 46.5 & - & - \\
\hline Soybean oil & 68.0 & 63.0 & 52.0 \\
\hline Dicalcium phosphate & 15.8 & 20.0 & 21.0 \\
\hline Sodium bicarbonate & 12.1 & 8.0 & 0.7 \\
\hline Methionine & 3.5 & 1.0 & - \\
\hline Salt & 3.0 & 3.0 & 3.0 \\
\hline Vitamin and mineral premix ${ }^{*}$ & 3.0 & 3.0 & 3.0 \\
\hline Total & 1000 & 1000 & 1000 \\
\hline \multicolumn{4}{|l|}{ Chemical analysis (as fed basis) } \\
\hline Dry matter & 931.6 & 906.1 & 907.7 \\
\hline Crude protein & 261.5 & 182.1 & 181.9 \\
\hline Crude fibre & 32.4 & 36.6 & 35.3 \\
\hline Crude fat & 65.6 & 63.3 & 31.5 \\
\hline Ash & 63.0 & 42.2 & 45.2 \\
\hline \multicolumn{4}{|l|}{ Calculated analysis } \\
\hline Metabolizable energy (MJ/kg) & 13.3 & 13.3 & 13.3 \\
\hline Lysine & 12.6 & 10.3 & 8.9 \\
\hline Methionine + cystine & 10.5 & 7.2 & 5.7 \\
\hline Calcium & 9.9 & 7.3 & 7.0 \\
\hline Phosphorus (total) & 8.0 & 8.0 & 8.0 \\
\hline
\end{tabular}

* Supplying per kg feed: $13000 \mathrm{IU}$ vitamin $\mathrm{A} ; 5000 \mathrm{IU}$ vitamin $\mathrm{D}_{3} ; 30 \mathrm{mg}$ vitamin $\mathrm{E} ; 3 \mathrm{mg}$ vitamin $\mathrm{K}_{3}$;

$1 \mathrm{mg}$ thiamine; $5 \mathrm{mg}$ riboflavin; $3 \mathrm{mg}$ pyridoxine; $0.02 \mathrm{mg}$ vitamin $\mathrm{B}_{12} ; 10 \mathrm{mg}$ niacin; $15 \mathrm{mg}$ pantothenic acid; $0.8 \mathrm{mg}$ folic acid; $0.05 \mathrm{mg}$ biotin; $10 \mathrm{mg}$ vitamin C; $480 \mathrm{mg}$ choline chloride; $100 \mathrm{mg} \mathrm{Zn} ; 120 \mathrm{mg} \mathrm{Mn;} 20 \mathrm{mg} \mathrm{Fe}$; $15 \mathrm{mg} \mathrm{Cu} ; 0.2 \mathrm{mg} \mathrm{Co} ; 1 \mathrm{mg} \mathrm{l;} 0.4 \mathrm{mg}$ Se.

The fatty acid composition of the breast and the thigh muscles samples was determined by gas chromatography. The protocol described by O'Fallon et al. (2007) was used to obtain fatty acid methyl esters from the frozen samples. Afterwards, the separation and quantification of the methyl esters were carried out with a gas chromatographic system (TraceGC model K07332, ThermoFinnigan, ThermoQuest, Milan, Italy) equipped with a flame ionization detector, a model CSW 1.7 chromatography station (CSW, DataApex Ltd, Prague, Czech Republic) and a fused silica capillary column, $30 \mathrm{~m} \times 0.25 \mathrm{~mm}$ i.d., coated with cyanopropyl polysiloxane (phase type SP-2380) with a film thickness of $0.20 \mu \mathrm{m}$ (Supelco, Bellefonte, Pa, USA). The chromatographic conditions were as follows: carrier: $\mathrm{N}_{2}$; flow: $1 \mathrm{~mL} / \mathrm{min}$; oven: temperature $70^{\circ} \mathrm{C}$ for $0.5 \mathrm{~min}$, increase $30^{\circ} \mathrm{C} / \mathrm{min}$ to $180^{\circ} \mathrm{C}$ for $10 \mathrm{~min}$, increase $5^{\circ} \mathrm{C} / \mathrm{min}$ to $225^{\circ} \mathrm{C}$ for $15 \mathrm{~min}$; inlet temperature: $250^{\circ} \mathrm{C}$; detector temperature: $250^{\circ} \mathrm{C}$; injection: $1 \mu \mathrm{L}$ with split 1/20. Fatty acid methyl ester retention times and 
elusion order were identified using as reference standards Supelco F.A.M.E Mix C8-C24 (C.N. 18918-1AMP), Supelco 37 Component FAME Mix (47885-U), Supelco linoleic acid methyl ester cis/trans isomers (4-7791) and Sigma Tridecanoic acid (T0502-5G), and accompanying Supelco reference material for the procedure. Fatty acids were quantified by peak area measurement and the results were expressed as percentage (\%) of the total peak areas for all quantified acids.

Each individual replication (cage) was used as an experimental unit. The statistical analysis was performed with IBM SPSS Statistics 20 statistical package (SPSS Inc., Chicago, IL, USA). One-way analysis of variance (ANOVA) was performed, using the groups as fixed factors. Post-hoc analysis was undertaken using Tukey's test at $P<0.050$ (Hsu, 1996). The homogeneity of the measurements was examined with Levene's test (Levene, 1960).

\section{Results and Discussion}

The effects of spirulina supplementation in broiler performance parameters are presented in Table 2. The live weight of the birds of the control and treated groups did not differ $(P>0.05)$ during the feeding trial, nor did the feed conversion ratio differ $(P>0.05)$ among groups. Mortality was very low (only one bird in the control group died) and therefore did not differ $(P>0.05)$ among groups. These results are in agreement with those of previous researchers (Ross \& Dominy, 1990; Venkataraman et al., 1994; Qureshi et al., 1996; Gongnet et al., 2001; Toyomizu et al., 2001), who recorded nonsignificant effects of dietary spirulina supplementation on performance parameters, although it has been reported that spirulina inclusion over 100 $\mathrm{g} / \mathrm{kg}$ could depress the birds' growth (Ross \& Dominy, 1990). In contrast, other researchers (Kharde et al., 2012; Shanmugapriya \& Saravana Babu, 2014) reported that dietary spirulina significantly improved weight gain and feed efficiency of chickens compared with the control groups. Furthermore, Bellof \& Alarcon (2013) reported that under organic farming, dietary spirulina supplementation improved growth and carcass performance parameters of broilers significantly. Contradictory results are possibly due to the different spirulina inclusion levels and quality in the present trials. In addition, secondary parameters, such as feed composition, housing conditions and production systems, might be reasons for the variation in the results of the present study.

Table 2 Effects of dietary spirulina on broiler performance parameters

\begin{tabular}{lllllll}
\hline & \multicolumn{3}{c}{ Group * } & SEM & P \\
\cline { 2 - 4 } & Control & S05 & S10 & & NS \\
\hline Live weight at 21 d (kg) & 0.774 & 0.733 & 0.740 & & 0.013 & NS \\
Final live weight at 42 d (kg) & 2.458 & 2.328 & 2.381 & 0.047 & NS \\
Feed conversion ratio & 2.070 & 2.132 & 2.103 & 0.023 & NS \\
Mortality (\%) & 2.5 & 0 & 0 & 0.833 & & \\
\hline
\end{tabular}

\footnotetext{
* Four replications per group.

Control: $0 \mathrm{~g}$ spirulina/kg feed; S05: $5 \mathrm{~g}$ spirulina/kg feed; S10: $10 \mathrm{~g}$ spirulina/kg feed. NS: Not significant $(P>0.05)$.
}

Table 3 describes the effect of dietary spirulina on broilers breast and thigh meat lipid oxidation after two and five days of refrigerated storage. There was no difference $(P>0.05)$ on the measured TBARS among the three groups, although lipid oxidation was progressively higher in the second measurement both in breast and thigh meat. The increased TBARS values in thigh muscle are likely due to the high haem iron and myoglobin contents of these muscles (Alasnier et al., 2000; Min et al., 2008). Meat acceptability and rancidity can be affected by TBARS. Levels and values of TBARS over $0.8 \mathrm{mg} / \mathrm{kg}$ meat could be considered indicative of rancidity in poultry meat (O'Neil et al., 1998), giving an oxidised flavour to the meat and making it unacceptable to consumers. This threshold value of $0.8 \mathrm{mg}$ TBARS $/ \mathrm{kg}$ meat is remarkably higher than the TBARS values observed in this trial.

The effects of dietary spirulina on the meat fatty acid profile of the broiler breast are shown in Table 4 . Group S10 had a higher $(P<0.05)$ concentration of lauric acid $(C 12: 0)$ compared with the control group. Group S10 had a higher $(P<0.05)$ concentration of 6-trans linoleic acid $(6$-trans-C18:2) in comparison with group S05, but not compared with the control group. Moreover, no significant differences were noticed for 
Table 3 Effect of dietary spirulina on breast and thigh muscle lipid oxidation (TBARS, mg malonaldehyde/kg muscle) after 2 and 5 days of refrigeration

\begin{tabular}{|c|c|c|c|c|c|}
\hline \multirow{2}{*}{ Breast muscle } & \multicolumn{3}{|c|}{ Group * } & \multirow{2}{*}{ SEM } & \multirow{2}{*}{$P$} \\
\hline & Control & S5 & S10 & & \\
\hline $2 \mathrm{~d}$ refrigeration & 0.148 & 0.140 & 0.113 & 0.016 & NS \\
\hline $5 \mathrm{~d}$ refrigeration & 0.285 & 0.433 & 0.334 & 0.048 & NS \\
\hline Increase between $2 d$ and $5 d$ & 0.137 & 0.311 & 0.221 & 0.042 & NS \\
\hline \multicolumn{6}{|l|}{ Thigh muscle } \\
\hline $2 \mathrm{~d}$ refrigeration & 0.156 & 0.137 & 0.138 & 0.018 & NS \\
\hline $5 \mathrm{~d}$ refrigeration & 0.376 & 0.451 & 0.256 & 0.044 & NS \\
\hline Increase between $2 d$ and $5 d$ & 0.220 & 0.314 & 0.118 & 0.044 & NS \\
\hline
\end{tabular}

* Four replications per group.

Control: $0 \mathrm{~g}$ spirulina/kg feed; S05: $5 \mathrm{~g}$ spirulina/kg feed; S10: $10 \mathrm{~g}$ spirulina/kg feed.

NS: Not significant $(P>0.05)$.

the other fatty acids, and the total saturated, unsaturated and polyunsaturated fatty acids. The effects of dietary spirulina on broiler thigh meat fatty acid profile are presented in Table 5. Group S05 had higher $(P$ $<0.05)$ concentrations of eicosatrienoic acid (C20:3n-3), arachidonic acid (C20:4n-6), eicosapentaenoic acid (C20:5n-3 EPA), lignoceric acid (C24:0), docosapentaenoic acid (C22:5n-3 DPA), docosahexaenoic acid (C22:6n-3 DHA), and lower $(P<0.05)$ concentrations of oleic acid (9-cis-C18:1), arachidic acid (C20:0), eicosenoic acid (C20:1n-9), compared with control group. Group S10 had higher $(P<0.05)$ concentrations of palmitoleic acid (C16:1), gamma-linolenic acid $(\mathrm{C} 18: 3 n-6)$ and a lower $(P<0.05)$ concentration of eicosatrienoic acid (C20:3n-3) compared with group S05, while it had a lower $(P<0.05)$ concentration of eicosenoic acid (C20:1n-9) compared with control group. Overall, monounsaturated fatty acids were higher $(P<0.05)$ for Group S05 compared with the control group, and polyunsaturated fatty acids were higher $(P$ $<0.05)$ for groups S05 and S10 than the control group, while saturated fatty acids did not differ $(P>0.05)$ among the three groups.

Fatty acid composition showed that dietary spirulina supplementation affected both the breast and thigh meat fatty acid profiles, but the effect was much more pronounced in the thigh meat. These findings cannot be compared with other research in broilers, since similar reports have not been found in recent literature, to the best of that authors' knowledge. This difference could be because raw chicken thigh meat contains an up to five times higher absolute amount of crude fat (about $40-140 \mathrm{~g} / \mathrm{kg}$ ) than raw chicken breast meat (about $10-30 \mathrm{~g} / \mathrm{kg}$ ), and the fatty acid composition can be different between these different muscle tissues possibly due to their different phospholipid contents (Botsoglou et al., 2002; Cortinas et al., 2004). Moreover, these differences in composition are affected by the combined result of endogenous fat synthesis and direct utilization of feed fat. Also, it is known (Cortinas et al., 2004; Zelenka et al., 2008) that different sources of fat in broiler diets directly affect the total amount and the percentages of individual fatty acids in the meat and subcutaneous fat. Thus it is possible to increase the percentage of polyunsaturated fatty acids.

Polyunsaturated fatty acids cannot be synthesized by humans. For this reason they should be included in the normal daily diet (FAO, 2008). These fatty acids play an important role in the production and metabolism of substances such as prostaglandins, thromboxanes and leukotrienes (FAO, 2008; Simopoulos, 2008). Furthermore, in the present trial, nutritionally important $n-3$ fatty acids, such as eicosapentaenoic acid (EPA), docosapentaenoic acid (DPA) and docosahexaenoic acid (DHA), were increased in the thigh meat. These fatty acids are not consumed in adequate amounts in modern Western societies (Simopoulos, 2008), and it has been reported that their consumption could benefit foetus growth and protect from numerous chronic diseases, that is, infections, cancer, asthma, depression, heart and autoimmune diseases (Simopoulos, 2002; FAO, 2008; Swanson et al., 2012). In addition, the increased consumption of unsaturated fatty acids, along with decreased consumption of saturated fatty acids, is considered beneficial, limiting the risk and the effects of cardiovascular and degenerative diseases (Cortinas et al., 2004; FAO, 2008; Reiner et al., 2011). 
Table 4 Effects of dietary spirulina on broiler breast meat fatty acid profile (\% fatty acid/total fatty acids)

\begin{tabular}{|c|c|c|c|c|c|c|}
\hline \multirow{2}{*}{ Fatty acids (FA) } & \multirow{2}{*}{ Common name } & \multicolumn{3}{|c|}{ Groups* } & \multirow{2}{*}{ SEM } & \multirow{2}{*}{$P$} \\
\hline & & Control & S05 & S10 & & \\
\hline 10:0 & Capric & 0.093 & 0.090 & 0.054 & 0.011 & NS \\
\hline $12: 0$ & Lauric & $0.021^{a}$ & $0.024^{a b}$ & $0.038^{b}$ & 0.002 & 0.021 \\
\hline $14: 0$ & Myristic & 0.336 & 0.344 & 0.367 & 0.017 & NS \\
\hline $14: 1$ & Myristoleic & 0.032 & 0.081 & 0.036 & 0.010 & NS \\
\hline 16:0 & Palmitic & 16.708 & 17.232 & 16.521 & 0.432 & NS \\
\hline $16: 1$ & Palmitoleic & 1.588 & 1.981 & 1.964 & 0.096 & NS \\
\hline 18:0 & Stearic & 9.184 & 8.106 & 8.870 & 0.338 & NS \\
\hline 9 trans-18:1 & trans-Oleic & 0.324 & 0.191 & 0.315 & 0.056 & NS \\
\hline 9 cis-18:1 & cis-Oleic & 26.948 & 26.970 & 29.193 & 0.622 & NS \\
\hline 6 trans-18:2 & trans-Linoleic & $0.044^{a b}$ & $0.036^{\mathrm{a}}$ & $0.055^{b}$ & 0.002 & 0.004 \\
\hline 6 cis-18:2 & cis-Linoleic & 26.412 & 28.541 & 26.430 & 0.843 & NS \\
\hline $18: 3 n-6$ & Y-Linolenic & 0.160 & 0.216 & 0.181 & 0.009 & NS \\
\hline $20: 0$ & Arachidic & 0.204 & 0.210 & 0.191 & 0.007 & NS \\
\hline $18: 3 n-3$ & a-Linolenic & 1.720 & 2.123 & 1.942 & 0.111 & NS \\
\hline $20: 1 n-9$ & Eicosenoic & 0.257 & 0.240 & 0.277 & 0.010 & NS \\
\hline $20: 2$ & Eicosadienoic & 0.601 & 0.510 & 0.537 & 0.041 & NS \\
\hline $20: 3 n-3$ & Eicosatrienoic & 0.838 & 0.716 & 0.704 & 0.055 & NS \\
\hline $20: 4 n-6$ & Arachidonic & 5.573 & 4.814 & 4.711 & 0.515 & NS \\
\hline $22: 1 n-9$ & Erucic & 0.035 & 0.029 & 0.027 & 0.007 & NS \\
\hline 20:5n-3 (EPA) & Eicosapentaenoic & 0.232 & 0.215 & 0.222 & 0.019 & NS \\
\hline $24: 0$ & Lignoceric & 1.237 & 1.022 & 1.039 & 0.111 & NS \\
\hline 22:5n-3 (DPA) & Docosapentaenoic & 0.874 & 0.770 & 0.782 & 0.079 & NS \\
\hline 22:6n-3 (DHA) & Docosahexaenoic & 0.859 & 0.784 & 0.717 & 0.078 & NS \\
\hline$\Sigma$ SFA & Total saturated & 28.418 & 27.551 & 27.582 & 0.622 & NS \\
\hline$\Sigma$ MUFA & Total monounsaturated & 29.775 & 29.942 & 32.373 & 0.634 & NS \\
\hline$\Sigma$ PUFA & Total polyunsaturated & 37.314 & 38.726 & 36.282 & 0.607 & NS \\
\hline
\end{tabular}

* Four replications per group.

Control: $0 \mathrm{~g}$ spirulina/kg feed; S05: $5 \mathrm{~g}$ spirulina/kg feed; S10: $10 \mathrm{~g}$ spirulina/kg feed.

${ }^{\mathrm{ab}}$ Values in the same row with no common superscript differ significantly at $P<0.05$.

NS: not significant $(P>0.05)$.

\section{Conclusion}

The dietary supplementation of spirulina $(5 \mathrm{~g} / \mathrm{kg}$ or $10 \mathrm{~g} / \mathrm{kg}$ ) in broiler diets affected the fatty acid composition of the broiler meat, without any significant negative impact on performance parameters and meat oxidative stability. Of the two inclusion levels of spirulina, $5 \mathrm{~g} / \mathrm{kg}$ increased the concentrations of certain vital and valuable polyunsaturated fatty acids, such as EPA, DPA, and DHA, in thigh meat. Therefore, spirulina could be a promising functional ingredient in broiler chicken nutrition. Nevertheless, more multidisciplinary research is required since this microalga fits the criteria for the development of potential functional ingredients in broiler nutrition. 
Table 5 Effects of dietary spirulina on broiler thigh meat fatty acid profile (\% fatty acid/total fatty acids)

\begin{tabular}{|c|c|c|c|c|c|c|}
\hline \multirow{2}{*}{ Fatty acids } & \multirow{2}{*}{ Common name } & \multicolumn{3}{|c|}{ Groups* } & \multirow{2}{*}{ SEM } & \multirow{2}{*}{$P$} \\
\hline & & Control & S05 & S10 & & \\
\hline 10:0 & Capric & 0.009 & 0.019 & 0.013 & 0.003 & NS \\
\hline 12:0 & Lauric & 0.021 & 0.038 & 0.026 & 0.003 & NS \\
\hline 14:0 & Myristic & 0.347 & 0.311 & 0.272 & 0.017 & NS \\
\hline $14: 1$ & Myristoleic & 0.047 & 0.044 & 0.054 & 0.003 & NS \\
\hline 16:0 & Palmitic & 17.229 & 16.852 & 16.701 & 0.190 & NS \\
\hline $16: 1$ & Palmitoleic & $1.938^{\mathrm{ab}}$ & $1.183^{\mathrm{a}}$ & $1.993^{\mathrm{b}}$ & 0.128 & 0.030 \\
\hline 18:0 & Stearic & 8.117 & 10.516 & 8.603 & 0.440 & NS \\
\hline 9 trans-18:1 & trans-Oleic & 0.323 & 0.268 & 0.311 & 0.048 & NS \\
\hline 9 cis-18:1 & cis-Oleic & $29.240^{b}$ & $19.838^{\mathrm{a}}$ & $25.442^{\mathrm{ab}}$ & 0.992 & 0.003 \\
\hline 6 trans- $18: 2$ & trans-Linoleic & 0.048 & 0.057 & 0.068 & 0.005 & NS \\
\hline 6 cis-18:2 & cis-Linoleic & 28.928 & 27.234 & 29.770 & 0.744 & NS \\
\hline $18: 3 n-6$ & y-Linolenic & $0.248^{\mathrm{ab}}$ & $0.210^{\mathrm{a}}$ & $0.281^{\mathrm{b}}$ & 0.011 & 0.042 \\
\hline $20: 0$ & Arachidic & $0.147^{\mathrm{b}}$ & $0.090^{\mathrm{a}}$ & $0.118^{\mathrm{ab}}$ & 0.008 & 0.028 \\
\hline $18: 3 n-3$ & a-Linolenic & 2.004 & 1.282 & 2.003 & 0.140 & NS \\
\hline $20: 1 n-9$ & Eicosenoic & $0.287^{b}$ & $0.177^{\mathrm{a}}$ & $0.207^{\mathrm{a}}$ & 0.012 & 0.003 \\
\hline $20: 2$ & Eicosadienoic & 0.523 & 0.909 & 0.616 & 0.067 & NS \\
\hline $20: 3 n-3$ & Eicosatrienoic & $0.729^{a}$ & $1.354^{\mathrm{b}}$ & $0.779^{\mathrm{a}}$ & 0.083 & 0.009 \\
\hline $20: 4 n-6$ & Arachidonic & $3.515^{\mathrm{a}}$ & $7.804^{\mathrm{b}}$ & $4.950^{\mathrm{ab}}$ & 0.546 & 0.013 \\
\hline $22: 1 n-9$ & Erucic & 0.010 & 0.010 & 0.019 & 0.005 & NS \\
\hline 20:5n-3 (EPA) & Eicosapentaenoic & $0.126^{\mathrm{a}}$ & $0.234^{\mathrm{b}}$ & $0.177^{\mathrm{ab}}$ & 0.015 & 0.029 \\
\hline $24: 0$ & Lignoceric & $0.795^{\mathrm{a}}$ & $1.624^{\mathrm{b}}$ & $0.956^{\mathrm{ab}}$ & 0.112 & 0.016 \\
\hline $22: 5 n-3$ (DPA) & Docosapentaenoic & $0.633^{\mathrm{a}}$ & $1.382^{\mathrm{b}}$ & $0.849^{\mathrm{ab}}$ & 0.097 & 0.014 \\
\hline $22: 6 n-3(\mathrm{DHA})$ & Docosahexaenoic & $0.692^{\mathrm{a}}$ & $1.435^{\mathrm{b}}$ & $0.813^{\mathrm{ab}}$ & 0.108 & 0.022 \\
\hline$\Sigma$ SFA & Total saturated & 27.159 & 30.154 & 27.165 & 0.666 & NS \\
\hline$\Sigma$ MUFA & Total monounsaturated & $32.242^{b}$ & $22.433^{\mathrm{a}}$ & $28.526^{\mathrm{ab}}$ & 1.048 & 0.004 \\
\hline$\Sigma$ PUFA & Total polyunsaturated & $37.447^{\mathrm{a}}$ & $41.901^{\mathrm{b}}$ & $40.305^{\mathrm{b}}$ & 0.450 & 0.002 \\
\hline
\end{tabular}

* Four replications per group.

Control: $0 \mathrm{~g}$ spirulina/kg feed; S05: $5 \mathrm{~g}$ spirulina/kg feed; S10: $10 \mathrm{~g}$ spirulina/kg feed.

${ }^{\mathrm{ab}}$ Values in the same row with no common superscript differ significantly at $P<0.05$.

NS: not significant $(P>0.05)$.

\section{Conflict of interest declaration}

The authors declare that there was no conflict of interest.

\section{References}

Abdulrahman, N.M. \& Hamad Ameed, H.J., 2014. Replacement of fishmeal with microalgae spirulina on common carp weight gain, meat and sensitive composition and survival. Pakistan J. Nutr. 13, 93-98.

Alasnier, C.A., Meynier, M., Viau, M. \& Gandemer, G., 2000. Hydrolytic and oxidative changes in the lipids of chicken breast and thigh muscles during refrigerated storage. J. Food Sci. 65, 9-14.

Alvarenga, R.R., Rodrigues, P.B., Cantarelli, V., Zangeronimo, M.G., Da Silva Junior, J.W., Da Silva, L.R., Dos Santos, L.M. \& Pereira, L.J., 2011. Energy values and chemical composition of spirulina (Spirulina platensis) evaluated with broilers. Braz. J. Anim. Sci. 40, 992-996.

AOAC, 2005. Official Methods of Analysis, (18th ed.). Association of Analytical Chemists, AOAC International, Arlington, Virginia, USA.

Batista, A.P., Gouveia, L., Bandarra, N.M., Franco, J.M. \& Raymundo, A., 2013. Comparison of microalgal biomass profiles as novel functional ingredient for food products. Algal Res. 2, 164-173. 
Becker, E.W., 1994. Nutrition. In: Microalgae: Biotechnology and Microbiology. Cambridge University Press, Cambridge. pp. 196-249.

Becker, E.W., 2007. Micro-algae as a source of protein. Biotechnol. Adv. 25, 207-210.

Bellof, G. \& Alarcon, S.C., 2013. Effect of Spirulina platensis in organic broiler production Archiv. Geflug. 77, 73-80.

Borowitzka, M.A., 1988. Vitamins and fine chemicals from microalgae. In: Micro-algal Biotechnology. Eds: Borowitzka, M.A., \& Borowitzka, L.J. Cambridge University Press, Cambridge. pp. 153-196.

Borowitzka, M.A., 2013. High-value products from microalgae - their development and commercialisation. J. Appl. Phycol. $25,743-756$.

Botsoglou, N.A., Florou-Paneri, P., Christaki, E., Fletouris, D.J. \& Spais, A.B., 2002. Effect of dietary oregano essential oil on performance of chickens and iron-induced lipid oxidation of breast, thigh and abdominal fat tissues. Br. Poult. Sci. 43, 223-230.

Carrillo, S., Lopez, E., Casas, M.M., Avila, E., Castillo, R.M., Carranco, M.E., Calvo, C. \& Perez-Gil, E., 2008. Potential use of seaweeds in the laying hen ration to improve the quality of n-3 fatty acid enriched eggs. J. Appl. Phycol. 20, 271-278.

Cavani, C., Petracci, M., Trocino, A. \& Xiccato, G., 2010. Advances in research on poultry and rabbit meat quality. Ital. J. Anim. Sci. 8, 741-750.

Christaki, E., Florou-Paneri, P. \& Bonos, E., 2011. Microalgae: a novel ingredient in nutrition. Int. J. Food Sci. Nutr. 62, 794-799.

Christaki, E., Karatzia, M., Bonos, E., Florou-Paneri, P. \& Karatzias, C., 2012. Effect of dietary Spirulina platensis on milk fatty acid profile of dairy cows. Asian J. Anim. Vet. Adv. 7, 597-604.

Christaki, E., Bonos, E., Giannenas, I. \& Florou-Paneri, P., 2013. Functional properties of carotenoids originating from algae. J. Sci. Food Agric. 93, 5-11.

Ciferri, O., 1983. Spirulina, the edible microorganism. Microbiol. Rev. 47, 551-578.

Colla, L.M., Muccillo-Baisch, A.L. \& Costa, J.A.V., 2008. Spirulina platensis effects on the levels of total cholesterol, HDL and triacylglycerols in rabbits fed with a hypercholesterolemic diet. Braz. Arch. Biol. Technol. 51, 405-411.

Cortinas, L., Villaverde, C., Galobart, J., Baucells, M.D., Codony, R. \& Barroeta, A.C., 2004. Fatty acid content in chicken thigh and breast as affected by dietary polyunsaturation level. Poult. Sci. 83, 1155-1164.

Draaisma, R.B., Wijffels, R.H., Slegers, P.E., Brentner, L.B., Roy, A. \& Barbosa, M.J., 2013. Food commodities from microalgae. Curr. Opin. Biotechnol. 24, 169-177.

EL-Sabagh, M.R., Eldaim, M.A.A., Mahboub, D.H. \& Abdel-Daim, M., 2014. Effects of Spirulina platensis algae on growth performance, antioxidative status and blood metabolites in fattening lambs. J. Agric. Sci. 6, 92-98.

Eriksen, N.T., 2008. Production of phycocyanin - a pigment with applications in biology, biotechnology, foods and medicine. Appl. Microbiol. Biotechnol. 80, 1-14.

FAO, 2008. Fats and fatty acids in human nutrition: Report of an expert consultation. FAO Food and Nutrition, Geneva.

Freitas, A.C., Rodrigues, D., Rocha-Santos, T.A.P., Gomes, A.M.P. \& Duarte, A.C., 2012. Marine biotechnology advances towards applications in new functional foods. Biotechnol. Adv. 30, 1506-1515.

Gerencser, Z., Szendro, Z., Matics, Z., Radnai, I., Kovacs, M., Nagy, I., Cullere, M., Dal Bosco, A. \& Zotte, D.A., 2014. Effect of dietary supplementation of spirulina (Arthrospira platensis) and thyme (Thymus vulgaris) on apparent digestibility and productive performance of growing rabbits. World Rabbit Sci. 22, 1-9.

Gongnet, G.P., Niess, E., Rodehutscord, M. \& Pfeffer, E., 2001. Algae-meal from lake Chad replacing soybean-meal in broiler diets. Archiv. Geflug. 65, 265-268.

Grinsteal, G.S., Tokach, M.D., Dritz, S.S., Goodband, R.D. \& Nelssen, J.L., 2000. Effects of Spirulina platensis on growth performance of weanling pigs. Anim. Feed Sci. Technol. 83, 237-247.

Habib, M.A.B., Parvin, M., Huntington, T.C. \& Hasan, M.R., 2008. A review on culture, production and use of spirulina as food for humans and feeds for domestic animals and fish. FAO Fish. Aquacult. C., 1034.

Holman, B.W.B. \& Malau-Aduli, A.E.O., 2013. Spirulina as a livestock supplement and animal feed. J. Anim. Physiol. Anim. Nutr. 97, 615-623.

Hsu, J.C., 1996. Multiple Comparisons: Theory and Methods. Chapman \& Hall / CRC, Boka Raton, FL, USA.

Hue, C., Hu, Y., Saito, H., Zhang, Z., Li, Z., Cai, Y., Ou, C., Lin, H. \& Imbs, A.B., 2002. Molecular species composition of glycolipids from Spirulina platensis. Food Chem. 77, 9-13.

Jimenez-Colmenero, F., Carballo, S. \& Cofrades, S., 2001. Healthier meat and meat products: Their role as functional foods. Meat Sci. 59, 5-13.

Kasapidou, E., Giannenas, I., Mitlianga, P., Sinapis, E., Bouloumpasi, E., Petrotos, K., Manouras, A. \& Kyriazakis, I., 2014. Effect of Melissa officinalis supplementation on growth performance and meat quality characteristics in organically produced broilers. Br. Poult. Sci. 55, 774-784.

Kharde, S.D., Shirbhate, R.N., Bahiram, K.B. \& Nipane, S.F., 2012. Effect of spirulina supplementation on growth performance of broilers. Indian J. Vet. Res. 21, 66-69.

Levene, H., 1960. Levene's Test. In: Contributions to Probability and Statistics: Essays in Honor of Harold Hotelling. Ed: Olkin, I., Stanford University Press, Stanford, CA, USA. pp. 278-292.

Lordan, S., Paul Ross, R. \& Stanton, C., 2011. Marine bioactives as functional food ingredients: Potential to reduce the incidence of chronic diseases. Mar. Drugs 9, 1056-1100.

Maoka, T., 2011. Carotenoids in marine animals. Mar. Drugs 9, 278-293.

Maries, Y.A., Samak, H.R. \& Ibrahem, M.A., 2012. Effect of using spirulina platensis algae as a feed additive for poultry diets: 1-productive and reproductive performances of local laying hens. Egypt. Poult. Sci. 31, 201-215.

Min, B., Nam, K.C., Cordray, J. \& Ahn, D.U., 2008. Endogenous factors affecting oxidative stability of beef loin, pork loin, and chicken breast and thigh meats. J. Food Sci. 73, C439-C446. 
Novus, 1992. Raw Material Compendium, 1st ed. Novus, Brussels, Belgium.

NRC, 1994. Nutrient Requirements of Poultry, 9th Rev. National Academy Press, Washington, USA.

O'Fallon, J.V., Busboom, J.R., Nelson, M.L. \& Gaskins, C.T., 2007. A direct method for fatty acid methyl ester synthesis: Application to wet meat tissues, oils and feedstuffs. J. Anim. Sci. 85, 1511-1521.

O'Neil, L.M., Galvin, K., Morrissey, P.A. \& Buckley, D.J., 1998. Comparison of effects of dietary olive oil, tallow and vitamin $\mathrm{E}$ on the quality of broiler meat and meat products. Br. Poult. Sci. 39, 365-371.

Peiretti, P.G. \& Meineri, G., 2008. Effects of diets with increasing levels of Spirulina platensis on the performance and apparent digestibility in growing rabbits. Livest. Sci. 118, 173-177.

Petracci, M., Bianchi, M., Mudalal, S. \& Cavani, C., 2013. Functional ingredients for poultry meat products. Trends Food Sci. Technol. 33, 27-39.

Plaza, M., Herrero, M., Cifuentes, A. \& Ibanez, E., 2009. Innovative natural functional ingredients from microalgae. J. Agric. Food Chem. 57, 7159-7170.

Qureshi, M.A., Garlich, J.D. \& Kidd, M.T., 1996. Dietary Spirulina platensis enhances humoral and cell-mediated immune functions in chickens. Immunopharmacol. Immunotoxicol. 18, 465-476.

Ravi, M., Lata De, S., Azharuddin, S. \& Paul, S.F.D., 2010. The beneficial effects of spirulina focusing on its immunomodulatory and antioxidant properties. Nutr. Diet. Suppl. 2, 73-83.

Reiner, Z., Catapano, A.L., Backer, G.D., Graham, I., Taskinen, M.R., Wiklund, O., Agewall, S., Alegria, E., Chapman, M.J., Durrington, P., Erdine, S., Halcox, J., Hobbs, R., Kjekshus, J., Filardi, P.P., Riccardi, G., Storey, R.F., Wood, D., Bax, J., Vahanian, A., Auricchio, A., Baumgartner, H., Ceconi, C., Dean, V., Deaton, C., Fagard, R., Filippatos, G., Funck-Brentano, C., Hasdai, D., Hobbs, R., Hoes, A., Kearney, P., Knuuti, J., Kolh, P., McDonagh, T., Moulin, C., Poldermans, D., Popescu, B.A., Reiner, Z., Sechtem, U., Sirnes, P.A., Tendera, M., Torbicki, A., Vardas, P., Widimsky, P. \& Windecker, S., 2011. ESC/EAS Guidelines for the management of dyslipidaemias: The Task Force for the management of dyslipidaemias of the European Society of Cardiology (ESC) and the European Atherosclerosis Society (EAS). Eur. Heart J. 34, 1769-1818.

Ross, E. \& Dominy, W., 1990. The nutritional value of dehydrated, blue-green algae (Spirulina platensis) for poultry. Poult. Sci. 69, 794-800.

Rymer, C.A. \& Givens, D.I., 2006. Effect of species and genotype on the efficiency of enrichment of poultry meat with n-3 polyunsaturated fatty acids. Lipids $41,455-451$.

Shanmugapriya, B. \& Saravana Babu, S., 2014. Supplementary effect of Spirulina platensis on performance, hematology and carcass yield of broiler chickens. Indian Streams Res. J. 4, 1-7.

Simkus, A., Oberauskas, V., Laugalis, J., Zelvyte, R., Monkeviciene, I., Sederevicius, A., Simkiene, A. \& Pauliukas, K., 2007. The effect of weed Spirulina platensis on the milk production in cows. Vet. Ir Zootechn. 38, 74-77.

Simopoulos, A.P., 2002. The importance of the ratio of omega-6/omega-3 essential fatty acids. Biomed. Pharmacother. $56,365-379$.

Simopoulos, A.P., 2008. The importance of the omega 6/omega 3 fatty acid ratio in cardiovascular disease and other chronic diseases. Exp. Biol. Med. 233, 674-688.

Spolaore, P., Joannis-Cassan, C., Duran, E. \& Isambert, A., 2006. Commercial applications of microalgae. J. Biosci. Bioeng. 101, 87-96.

Swanson, D., Block, R. \& Mousa, S.A., 2012. Omega-3 fatty acids EPA and DHA: Health benefits throughout life. Adv. Nutr. 3, 1-7.

Tonon, T., Harvey, D., Larson, T.R. \& Graham, I.A., 2002. Long chain polyunsaturated fatty acid production and partitioning to triacylglycerols in four microalgae. Phytochem. 61, 15-24.

Toyomizu, M., Sato, K., Taroda, H., Kato, T. \& Akiba, Y., 2001. Effects of dietary spirulina on meat colour in muscle of broiler chickens. Br. Poult. Sci. 42, 197-202.

Tzovenis, I., De Pauw, N. \& Sorgeloos, P., 2003. Optimisation of T-ISO biomass production rich in essential fatty acids: I. Effect of different light regimes on growth and biomass production. Aquaculture 216, 203-222.

Venkataraman, L.V., Somasekaran, T. \& Becker, E.W., 1994. Replacement value of blue-green alga (Spirulina platensis) for fishmeal and a vitamin-mineral premix for broiler chicks. Br. Poult. Sci. 35, 373-381.

Vyncke, W., 1975. Evaluation of the direct thiobarbituric acid extraction method for determining oxidative rancidity in mackerel (Scomber scombrus L.). Fette, Seifen, Anstrichm. 77, 239-240.

Yukino, T., Hayashi, M., Inoue, Y., Imamura, J., Nagano, N. \& Murata, H., 2005. Preparation of docosahexaenoic acid fortified Spirulina platensis and its lipid and fatty acid compositions. Nippon Shoku. Kag. Kai. 71, 74-79.

Zahroojian, N., Moravej, H. \& Shivazad, M., 2013. Effects of dietary marine algae (Spirulina platensis) on egg quality and production performance of laying hens. J. Agric. Sci. Technol. 15, 1353-1360.

Zelenka, J., Schneiderova, D., Mrkvicova, E. \& Dolezal, P., 2008. The effect of dietary linseed oils with different fatty acid pattern on the content of fatty acids in chicken meat. Veterinarni Medicina 53, 77-85. 